\title{
Comparison of Acehnese Pidie Dialect Variations between Acehnese Nagan Raya Dialects of Acehnese People in Peukan Baro District
}

\author{
Nofiana S. ${ }^{1}$, Putri Malahayati \\ ${ }^{1,2}$ University of Jabal Ghafur, Indonesia \\ nofiana8788@gmail.com,putri.malahayati@yahoo.co.id
}

\section{Abstract}

This research is entitled "Comparison of the Acehnese dialect of the Pidie dialect with the Nagan Raya dialect of Acehnese people in the Peukan Baro district". The formulation of the problem is, How do the variations of the Acehnese dialect of the Pidie dialect compare with the Acehnese dialect of the Nagan Raya in the Acehnese people of Peukan Baro District when interacting using the original speech of the two dialects. This researchaim to describe the comparison of variations in the Acehnese language found in the Acehnese dialect of Pidie with the Acehnese dialect of Nagan Raya, which is used by the Nagan Raya community who live in the Peukan Baro sub-district, when interacting using the native speech of the two regions. The method used in this study is a descriptive method with a qualitative approach. The main data source in this study is the Acehnese speaking community who live in Peukan Baro sub-district. Data was collected by using interview and documentation test techniques. The results of this study indicate that the comparison of language variations based on the usage spoken by the community: (1) comparative data of Acehnese language variations in the form of nouns; (2) comparative data of Acehnese language variations in the form of verbs; (4) comparative data on the variation of the Acehnese language in terms of speech belonging to customs, directions, and kinship calls.
\end{abstract}

Keywords

acehnese pidie dialect; qualitative approach; acehnese nagan raya dialects

\section{Introduction}

Suwarna (2002:4) says that "Language is the main tool to communicate in human life, both individually and socially collective". Language is a system of sound symbols that are meaningful and articulate (generated by speech instruments) that are arbitrary and conventional, which are used as a means of communication by a group of people to give birth to feelings and thoughts (Wibowo, 2001: 3). Keraf (2004:2) argues that "Language is a communication system that uses arbitrary vocal symbols (speech sounds), which can be strengthened by real physical movements, it is a symbol because of the series of sounds produced by the speech apparatus. Humans must be given a certain meaning, which refers to something that can be absorbed by the five senses. Based on the opinions of the experts above, it can be concluded that language has an important role in human life, namely as a communication tool used in people's lives. Therefore, language is said to be an inseparable part of human life.

Based on data from previous research, Wildan (2002:1) states that in Aceh there are nine languages, namely, Acehnese, Gayo language, Alas language, Tamiang language, Aneuk Jamèe language, Kluet language, Singkil language, Simeulu language, and Haloban language. . In addition, the regional language congress in Banda Aceh in November 2007 (Toha et al., 2008) stated that in Aceh there were 13 languages, including; Acehnese, 
Gayo, Aneuk Jamèe, Kluet, Tamiang, Julo, Haloban, Pak-pak, Nias, Lekon, Sigulai, Devayan, and Alas. In line with the expert opinion stated above, the researcher chose one of the regional languages to be used as a data source in this study, namely the Acehnese language.

The Aceh region is an area that has a central government consisting of 23 districts, in this study the researchers chose one of the districts in the Aceh area, namely Pidie district. Pidie Regency is one of the regencies in the province of Aceh, Indonesia, the capital of which is Sigli. After the division, there are 23 sub-districts in Pidie district and 730 villages, one of which is Peukan Baro sub-district with a population of about $\pm 20,314$ people.Based on the explanation above, the researcher chose regional dialects as the direction of the research study. This is because this opinion has a relationship with the direction of the title of the research being studied at this time. Therefore, the researcher took the dialect of the regional language, namely the Acehnese dialect of the Pidie dialect with the Acehnese dialect of the Nagan Raya. In this study, researchers only focused on the study of Acehnese dialects in only two districts, namely Pidie district and Nagan Raya district.

The formulation of the problem in this study is "How do the variations of the Acehnese dialect of the Pidie dialect compare with the Acehnese dialect of the Nagan Raya in the Acehnese people of Peukan Baro District when interacting using the original speech of the two dialects?". The purpose of this study is to describe the comparison of variations in the Acehnese language found in the Acehnese dialect of Pidie with the Acehnese dialect of Nagan Raya, which is used by the Nagan Raya community who live in the Peukan Baro sub-district, when interacting using the native speech of the two regions.

\section{Review of Literature}

Variation is an action or result of a change from the original state or an interlude, Alwi, et al (2005:1259). In other words, variation can be said to be the appearance of certain traits that cause one organism to differ from other organisms of the same type. In social life there are also several variations, one of which is language. Language variation or language variety is the use of language according to the user, which varies according to the topic being discussed, according to the relationship between the speaker, the interlocutor, and the person being discussed and according to the medium of conversation, Alwi, et al (2003: 902). According to Chaer (2010: 62), language variation is the diversity of languages caused by the existence of social interaction activities carried out by very diverse communities or groups and caused by non-homogeneous speakers.

The use of language variations in social life can be seen from its distribution which is viewed from various points of view. Based on its use, Chaer and Agustina (2004:62) distinguish language variations into four aspects of use, including: (1) variations in terms of speakers, (2) variations from users, (3) variations in terms of formality, and (4) variations in terms of facilities.Language variations This happens not only because the speakers are not homogeneous, but also the social interaction activities they do are very diverse (Chaer and Agustina, 2004: 61).

In dealing with members of society, humans use various variations of language so that it is interesting and the meaning conveyed can be well received. The factors that cause language variation are: location factors (where a community interacts), and social factors (a person's social position in society). In addition, language variations can also be influenced by ethnicity (culture) and religion (beliefs) of a society. In this case there are two main sources that cause the complexity of dialect distribution. The first source is 
geographic mobility, individuals move from one place to another carrying their dialect, even if they change it to adapt to their new environment. A second source of complexity is the fact that geography is only one relevant factor, and other factors are social class, gender, intermarriage, and age. Ramlan (2018) stated that the relationship between society and language is emerged with a number of variations. According to Ismail et al (2019) Social change is a change in the interaction relationship between people, organizations or communities, it can involve social structures, values and norms and roles.

According to Nadra (2009: 1), the word dialect comes from the Greek dialectos which is used to refer to the state of language in Greece which shows small differences in the language they use. Dialect can refer to variations caused by regional differences. Dialects can also be used to distinguish speech from the point of view of social class and groups that differ from other groups or as a regional feature and from which region the speaker comes from.

Talking about the dialect used by local people who live in an area. Sumarsono (2002:25) states that the dialect based on its usage is divided into four parts, namely; regional dialect, social dialect, temporal dialect, and functional dialect. Sumarsono (2002:21) argues that "The language of a group of people who occupy a certain area is called a dialect. Each region has a variety of languages, giving rise to variations for speakers. Language variation or language variety is the use of language according to the user, which varies according to the topic being discussed, according to the relationship between the speaker, the interlocutor, and the person being discussed and according to the medium of conversation, Alwi, et al (2003: 902). Based on this diversity, various language variations appear in each region in Aceh. Along with the emergence of language variations, dialects also experience variations.

The dialect variations used by the community as Acehnese speakers are more often found in terms of words. In this case, there are certain words that are not used by native speakers of the area, but are used by foreign speakers. Words like these are included in the dialect variations of the language owned by each region. Like the word [barōh] used by the people of Aceh in general which means to show direction. However, some native speakers of the Pidie dialect interpret the word as the direction of the West. Another example is the name for Acehnese food, in Acehnese the Pidie dialect is often called [timphan], while there are other Acehnese dialects that call it [lèupék] which has the same meaning.

\section{Research Methods}

The approach used in this study is a qualitative approach. According to Sugiyono (2009:15), qualitative research methods are research used to investigate, find, describe, and explain the quality or privilege of social influences that cannot be explained, measured or described through a quantitative approach. The type of research used in this research is descriptive ethnographic and analysis. In this study, researchers first sort out which people are native to the Acehnese people with the Pidie dialect and the Acehnese people with the Nagan Raya dialect. This is done by researchers to make it easier to analyze the comparison of language variations caused by the two languages spoken by the local community.

Researchers first describe the ethnography of language and language dialects. Researchers have determined two different dialects, but live in the same area, namely Peukan Baro sub-district. Several people have been identified by researchers who are indigenous Acehnese who use the Pidie dialect and the Nagan Raya dialect. After being identified, the researcher will analyze the Acehnese dialect of the Pidie dialect with the 
Acehnese dialect of the Nagan Raya. Researchers will describe the ethnography of language and language dialects. Researchers have determined two different dialects, but live in the same area, namely Peukan Baro sub-district. Several people have been identified by researchers who are indigenous Acehnese who use the Pidie dialect and the Nagan Raya dialect.

The main data in this study is about the dialects of languages that exist in the Aceh area, namely in the Peukan Baro sub-district. Other data in the form of supporting data such as written documents. The researcher will compare the language variations that exist in the Acehnese dialect, whether it is in the form of differences, similarities, or changes in meaning. This will be explained through written analysis, regarding the dialect of the language, as well as information about the people who live in the Peukan Baro sub-district area. To facilitate data collection, the author will use a table to describe the results of the comparative analysis of language variations that have been studied.

The source of data in this study is the Acehnese speaking community. After the researchers collected the informants, then grouped them into two groups. The two groups basically know more about the Pidie dialect of Aceh and the Nagan Raya dialect of Aceh. Furthermore, the researcher will analyze the comparison of language variations that arise from the two dialects. The types of data that will be described in this study can be grouped into three groups of data, namely (1) data on variations in the Acehnese language in the Peukan Baro sub-district, (2) data on the Acehnese dialect of the Pidie community and the Nagan Raya community in Peukan Baro sub-district, (3) comparative data on the variation of the Acehnese dialect of the Pidie dialect with the Acehnese dialect of the Nagan Raya.

Data collection techniques used in this study were interviews and documentation. The data collection in this study was carried out using the following techniques (steps): (1) the researcher first recorded the people who spoke the Pidie dialect with the Nagan Raya dialect speakers in the Peukan Baro sub-district, (2) the researchers searched for informants and then conducted interviews with the Acehnese speakers. Pidie dialect and Nagan Raya dialect speakers in Peukan Baro sub-district, (3) the researcher sorts the data according to the speaker's dialect, then analyzes it in the form of a diagram (4) the researcher examines the comparison of the variations of the Acehnese Pidie dialect with the Nagan Raya dialect. The instrument used in this study was audio in the form of a voice recorder in the form of a cellphone or mobile phone, which was used during interviews.

The data analysis technique used in this research is domain analysis, which is in the form of an analysis of the region or region. Data analysis in this study was carried out through the following stages: (1) researchers recorded data on variations in Acehnese dialects in the Peukan Baro sub-district, (2) the researcher records, listens, listens, and records what Acehnese language is spoken when conducting interviews with informants, (3) the researcher compares the Acehnese dialect variations in the Acehnese Pidie and Nagan Raya dialects, then lists them according to the sections provided have been determined, and classified according to their respective language dialect groups. 


\section{Results and Discussion}

This chapter presents information about the Aceh region in the form of districts/cities, sub-districts and mukims and gampongs in Peukan Baro sub-district, in order to strengthen the results of research that has been carried out by researchers. In addition, it will also explain the results of the comparative analysis of the variation of the Acehnese Pidie dialect with the Nagan Raya dialect of Aceh language found in the social interactions of the people who live in the Peukan Baro sub-district. Data exposure is done by mentioning languages or words that have a comparison of language variations, from the two Acehnese languages and different dialects.

Table 1. List of Mukim and Gampong in Peukan Baro District

\begin{tabular}{|c|c|c|c|c|c|c|}
\hline \multicolumn{7}{|c|}{ Number of Mukim and Gampong in Peukan Baro District } \\
\hline No. & $\begin{array}{c}\text { Mukim } \\
\text { Mesjid } \\
\text { Baro } \\
\end{array}$ & $\begin{array}{l}\text { Mukim } \\
\text { Bambi }\end{array}$ & $\begin{array}{l}\text { Mukim } \\
\text { Pineung }\end{array}$ & $\begin{array}{c}\text { Mukim } \\
\text { Guci } \\
\text { Rumpong }\end{array}$ & $\begin{array}{c}\text { Mukim } \\
\text { Krueng } \\
\text { Seumideun }\end{array}$ & $\begin{array}{l}\text { Mukim } \\
\text { Krueng } \\
\text { Dayah }\end{array}$ \\
\hline 1. & $\begin{array}{l}\text { Côt } \\
\text { Mulu }\end{array}$ & $\begin{array}{c}\text { Bale } \\
\text { Rastng }\end{array}$ & $\begin{array}{c}\text { Bale } \\
\text { Pineung }\end{array}$ & $\begin{array}{l}\text { Dayah } \\
\text { Seumide } \\
\text { uen }\end{array}$ & $\begin{array}{c}\text { Blang } \\
\text { Krueng } \\
\text { Seumideuen }\end{array}$ & $\begin{array}{l}\text { Estuary } \\
\text { Dayah }\end{array}$ \\
\hline 2. & Dayah & $\begin{array}{l}\text { Blang } \\
\text { Raya }\end{array}$ & $\begin{array}{l}\text { Arabic } \\
\text { bluek }\end{array}$ & Mosque & Jurông & Jim \\
\hline 3. & Bubue & $\begin{array}{l}\text { Dayah } \\
\text { Tengku }\end{array}$ & $\begin{array}{l}\text { Mé } \\
\text { Tanôh }\end{array}$ & $\begin{array}{c}\text { Rumpông . } \\
\text { Jar }\end{array}$ & $\begin{array}{c}\text { Krueng } \\
\text { Seumideuen }\end{array}$ & Palm oil \\
\hline 4. & $\begin{array}{l}\text { Two } \\
\text { Paya }\end{array}$ & $\begin{array}{l}\text { Dayah } \\
\text { Sukôn }\end{array}$ & $\begin{array}{l}\text { Meunjé } \\
\text { Mosque }\end{array}$ & $\begin{array}{c}\text { Lueng } \\
\text { Guci } \\
\text { Rumpông }\end{array}$ & $\begin{array}{l}\text { Mé Krueng } \\
\text { Seumideuen }\end{array}$ & $\begin{array}{c}\text { Meuleuwe } \\
\text { uk }\end{array}$ \\
\hline 5. & $\begin{array}{l}\text { Kupula } \\
\text { Ramba } \\
\text { yan }\end{array}$ & $\begin{array}{c}\text { Gorgeous } \\
\text { Gorge }\end{array}$ & Puùk & Waido & $\begin{array}{c}\text { Raya } \\
\text { Krueng } \\
\text { Seumideu } \\
\text { en }\end{array}$ & Keutapang \\
\hline 6. & $\begin{array}{l}\text { Lueng } \\
\text { Ramba } \\
\text { yanbay }\end{array}$ & $\begin{array}{l}\text { Lueng } \\
\text { Mosque }\end{array}$ & $\begin{array}{l}\text { Damn } \\
\text { Alèt }\end{array}$ & $\begin{array}{l}\text { Reuba } \\
\text { Waido }\end{array}$ & $\begin{array}{c}\text { Sukôn } \\
\text { Krueng } \\
\text { Seumideuen }\end{array}$ & $\begin{array}{l}\text { Uleè } \\
\text { Tutue }\end{array}$ \\
\hline 7. & $\begin{array}{c}\text { Sumbee } \\
\text { Buga }\end{array}$ & Me Hagu & & $\begin{array}{l}\text { Waido } \\
\text { Beetle }\end{array}$ & Keurembôk & \\
\hline 8. & $\begin{array}{c}\text { Tanjô ng } \\
\text { Hagu }\end{array}$ & $\begin{array}{c}\text { Teungôh } \\
\text { Barôh }\end{array}$ & & $\begin{array}{c}\text { Mè } \\
\text { Keureukôn }\end{array}$ & $\begin{array}{c}\text { Kabat } \\
\text { Seupeng }\end{array}$ & \\
\hline 9. & & & & $\begin{array}{c}\text { Mè } \\
\text { Lampôh } \\
\text { Saka }\end{array}$ & $\begin{array}{l}\text { Uleè Côt } \\
\text { Seupeng }\end{array}$ & \\
\hline 10. & & & & $\begin{array}{l}\text { Cempala } \\
\text { Kunèng }\end{array}$ & $\begin{array}{c}\text { Blang } \\
\text { Seupeng }\end{array}$ & \\
\hline 11. & & & & $\begin{array}{l}\text { Peunayông } \\
\text { Seupeng }\end{array}$ & & \\
\hline 12. & & & & $\begin{array}{l}\text { Leuhôb } \\
\text { Seupeng }\end{array}$ & & \\
\hline
\end{tabular}


After getting the data, the researchers conducted research on villages in Peukan Baro sub-district by collecting several sources of native Acehnese speakers with the Pidie dialect and the Acehnese dialect of Nagan Raya. In the comparison of language variations, there are similarities, differences, combinations, parables, and changes that will occur in a word, sentence, and meaning in the language used. As is the case, the Pidie dialect Acehnese language and the Nagan Raya dialect Acehnese language experience similarities, differences, and changes in the meanings contained by the two languages. To make it easier to analyze the comparison of language variations against the Acehnese language in the use of the Pidie and Nagan Raya dialects in community social interactions, it will be presented in the form of the table below.

Table 2. Comparative Data of Acehnese Language Variations in the Form of Nouns

\begin{tabular}{|c|c|c|c|}
\hline No. & Pidie dialect & $\begin{array}{c}\text { Acehnese dialect } \\
\text { Nagan Raya } \\
\end{array}$ & Information \\
\hline 1. & $\begin{array}{l}\text { Môk (Mok, a tool used } \\
\text { to measure rice, shaped } \\
\text { like a large cup from a } \\
\text { can). }\end{array}$ & $\begin{array}{l}\text { Môk (Mok, a tool used } \\
\text { for a type of glass used } \\
\text { to hold drinking water) }\end{array}$ & $\begin{array}{l}\text { The word is the same } \\
\text { word and is used by } \\
\text { both speakers in both } \\
\text { areas, but has different } \\
\text { meanings and uses. }\end{array}$ \\
\hline 2. & $\begin{array}{c}\text { Embeè (Bucket, a } \\
\text { cylindrical water } \\
\text { container made of } \\
\text { plastic, zinc, etc., used } \\
\text { to hold water, and so } \\
\text { on). }\end{array}$ & $\begin{array}{c}\text { Ayan (Bucket, a } \\
\text { cylindrical water } \\
\text { container made of } \\
\text { plastic, zinc, etc., used } \\
\text { to hold water, and so } \\
\text { on). }\end{array}$ & $\begin{array}{l}\text { These words are } \\
\text { different words and are } \\
\text { used by both speakers in } \\
\text { the two regions, } \\
\text { although the words are } \\
\text { different but have the } \\
\text { same meaning and use. }\end{array}$ \\
\hline 3. & $\begin{array}{c}\text { Bench (Made of plank, } \\
\text { wood, etc., which has } \\
\text { legs and is used as a } \\
\text { seat). }\end{array}$ & $\begin{array}{l}\text { LapëkDuk (Made of } \\
\text { boards, wood, etc., } \\
\text { which have legs and are } \\
\text { used as a seat). }\end{array}$ & $\begin{array}{l}\text { These words are } \\
\text { different words and are } \\
\text { used by both speakers in } \\
\text { the two regions, } \\
\text { although the words are } \\
\text { different but have the } \\
\text { same meaning and use. }\end{array}$ \\
\hline 4. & $\begin{array}{l}\text { Jindéla (Window, } \\
\text { opening that can be } \\
\text { closed, a device used } \\
\text { as air ventilation, or a } \\
\text { place for air to enter } \\
\text { and exit a building) }\end{array}$ & $\begin{array}{l}\text { Window (windows, } \\
\text { openings that can be } \\
\text { closed, devices used as } \\
\text { air vents in a building) }\end{array}$ & $\begin{array}{l}\text { These words are } \\
\text { different words and are } \\
\text { used by both speakers in } \\
\text { the two regions, } \\
\text { although the words are } \\
\text { different but have the } \\
\text { same meaning and use. }\end{array}$ \\
\hline 5. & $\begin{array}{l}\text { Abah Rèt (Fence gate, } \\
\text { a tool used as a barrier } \\
\text { or entrance to a } \\
\text { building such as a } \\
\text { house, office, school, } \\
\text { and so on). }\end{array}$ & $\begin{array}{l}\text { Pintô Rèt (Fence gate, a } \\
\text { tool used as a barrier or } \\
\text { entrance to a building } \\
\text { such as a house, office, } \\
\text { school, and so on). }\end{array}$ & $\begin{array}{l}\text { These words are } \\
\text { different words and are } \\
\text { used by both speakers in } \\
\text { the two regions, } \\
\text { although the words are } \\
\text { different but have the } \\
\text { same meaning and use. }\end{array}$ \\
\hline
\end{tabular}


Table 3. Comparative Data on Acehnese Language Variations in Verb Forms

\begin{tabular}{|c|c|c|c|}
\hline No. & Pidie dialect of Aceh & $\begin{array}{l}\text { Acehnese dialect } \\
\text { Nagan Raya }\end{array}$ & Information \\
\hline 1. & $\begin{array}{l}\text { Peugah haba } \\
\text { (Speaking), }\end{array}$ & $\begin{array}{l}\text { Marièt when pronounced } \\
/ \mathrm{r} / \text { melts (Speaking) }\end{array}$ & $\begin{array}{c}\text { These words are } \\
\text { different words and are } \\
\text { used by both speakers in } \\
\text { the two regions, } \\
\text { although the words are } \\
\text { different but have the } \\
\text { same meaning and } \\
\text { actions, such as } \\
\text { speaking by one person, } \\
\text { more than one person, } \\
\text { or often referred to as } \\
\text { interaction between one } \\
\text { person and another. } \\
\text { other people. }\end{array}$ \\
\hline 2. & $\begin{array}{l}\text { Meuayang (Joking, } \\
\text { chatting, or } \\
\text { joking/joking) }\end{array}$ & $\begin{array}{l}\text { Meukra, when } \\
\text { pronounced } / r / \text { melts } \\
\text { (Joking, chatting, or } \\
\text { joking/joking) }\end{array}$ & $\begin{array}{c}\text { These words are } \\
\text { different words and are } \\
\text { used by both speakers in } \\
\text { the two regions, } \\
\text { although the words are } \\
\text { different but have the } \\
\text { same meaning and } \\
\text { action. }\end{array}$ \\
\hline 3. & $\begin{array}{c}\text { Cart/ seurapa } \\
\text { (Swearing, saying bad } \\
\text { things to other people) }\end{array}$ & $\begin{array}{c}\text { Teunak (Insults, saying } \\
\text { bad things to other } \\
\text { people) }\end{array}$ & $\begin{array}{c}\text { These words are } \\
\text { different words and are } \\
\text { used by both speakers in } \\
\text { the two regions, } \\
\text { although the words are } \\
\text { different but have the } \\
\text { same meaning and } \\
\text { action. }\end{array}$ \\
\hline 4. & $\begin{array}{c}\text { Grôp (Base word), } \\
\text { Grôp- Grôp (Repeat), } \\
\text { which means to jump, } \\
\text { jump. }\end{array}$ & $\begin{array}{l}\text { Grôp (Base word), } \\
\text { Grôp- Grôp (Repeat), } \\
\text { which means to jump, } \\
\text { jump. }\end{array}$ & $\begin{array}{l}\text { The word is the same } \\
\text { word and is used by } \\
\text { both speakers in the two } \\
\text { regions, although the } \\
\text { word is the same, it has } \\
\text { the same meaning and } \\
\text { action, but what } \\
\text { distinguishes it is when } \\
\text { it is spoken. When using } \\
\text { the Nagan Raya dialect, } \\
\text { the sound /r/ melts, or } \\
\text { the /r/ sounds unclear. }\end{array}$ \\
\hline 5. & $\begin{array}{l}\text { Crôh (base word), } \\
\text { meucrôh (using the } \\
\text { prefix me-) which } \\
\text { means to fry/fry. }\end{array}$ & $\begin{array}{l}\text { Crôh (basic words), } \\
\text { meucrôh (basic words } \\
\text { using the prefix me-) } \\
\text { which means to fry/fry }\end{array}$ & $\begin{array}{l}\text { The word is the same } \\
\text { word and is used by } \\
\text { both speakers in the two } \\
\text { regions, although the }\end{array}$ \\
\hline
\end{tabular}




\begin{tabular}{|l|l|c|}
\hline & $\begin{array}{c}\text { word is the same, it has } \\
\text { the same meaning and } \\
\text { action, but what } \\
\text { distinguishes it is when } \\
\text { it is spoken. When using } \\
\text { the Nagan Raya dialect, } \\
\text { the sound } / \mathrm{r} / \text { melts, or } \\
\text { the } / \mathrm{r} / \text { sounds unclear. }\end{array}$ \\
\hline
\end{tabular}

Table 4. Comparative Data on Acehnese Language Variations in Speech Terms Classified in Customs, Directions, and Kinship Calls

\begin{tabular}{|c|c|c|c|}
\hline No. & Pidie dialect & $\begin{array}{c}\text { Acehnese dialect } \\
\text { Nagan Raya }\end{array}$ & Information \\
\hline 1. & $\begin{array}{c}\text { Keumawëh (A custom } \\
\text { to accompany or } \\
\text { celebrate a woman } \\
\text { who is pregnant with } \\
\text { her baby) }\end{array}$ & $\begin{array}{l}\text { Ba Bu Raya Pruet (A } \\
\text { custom to accompany or } \\
\text { celebrate a woman who } \\
\text { is pregnant with her } \\
\text { baby for seven months) }\end{array}$ & $\begin{array}{l}\text { These words are different } \\
\text { words and are used by } \\
\text { both speakers in the two } \\
\text { regions, even though the } \\
\text { words are different but } \\
\text { have the same meaning, } \\
\text { purpose, and actions. }\end{array}$ \\
\hline 2. & $\begin{array}{c}\text { Barôh (West, which is } \\
\text { a word that shows } \\
\text { direction). }\end{array}$ & $\begin{array}{c}\text { Barôh (West, which is a } \\
\text { word that shows } \\
\text { direction). }\end{array}$ & $\begin{array}{l}\text { The word is the same } \\
\text { word and is used by both } \\
\text { speakers in the two } \\
\text { regions, but has a } \\
\text { different meaning. In the } \\
\text { Acehnese dialect of Pidie } \\
\text { the word 'barôh' means } \\
\text { pointing towards the } \\
\text { West, while in the } \\
\text { Acehnese dialect of } \\
\text { Nagan Raya the word } \\
\text { means pointing } \\
\text { downwards. }\end{array}$ \\
\hline 3. & $\begin{array}{l}\text { Tunông (South, i.e. } \\
\text { word that indicates } \\
\text { direction). }\end{array}$ & $\begin{array}{l}\text { Mudèk (South, i.e. word } \\
\text { that shows direction). }\end{array}$ & $\begin{array}{l}\text { These words are different } \\
\text { words and are used by } \\
\text { both speakers in the two } \\
\text { regions, even though the } \\
\text { words are different but } \\
\text { have the same meaning, } \\
\text { purpose, and actions. }\end{array}$ \\
\hline 4. & $\begin{array}{l}\text { Apacut (Uncle, } \\
\text { kinship call from the } \\
\text { sibling of the child's } \\
\text { father or mother). }\end{array}$ & $\begin{array}{l}\text { Abak (Uncle, kinship } \\
\text { call from the sibling of } \\
\text { the child's father or } \\
\text { mother). }\end{array}$ & $\begin{array}{l}\text { These words are different } \\
\text { words and are used by } \\
\text { both speakers in the two } \\
\text { regions, even though the } \\
\text { words are different but } \\
\text { have the same meaning, } \\
\text { purpose, and actions. }\end{array}$ \\
\hline
\end{tabular}




\begin{tabular}{|c|c|c|c|}
\hline 5. & $\begin{array}{c}\text { Dû (Father / father, } \\
\text { nickname or other } \\
\text { designation for a } \\
\text { father). }\end{array}$ & $\begin{array}{c}\text { Kû (Father / father, } \\
\text { nickname or other } \\
\text { designation for a father). }\end{array}$ & $\begin{array}{c}\text { These words are different } \\
\text { words and are used by } \\
\text { both speakers in the two } \\
\text { regions, although the } \\
\text { words are different but } \\
\text { have the same meaning } \\
\text { and purpose. }\end{array}$ \\
& & \\
\end{tabular}

Based on the results of the research above, it shows that the comparison of language variations in the Pidie dialect with the Nagan Raya dialect in the Acehnese people in the Peukan Baro sub-district, occurs in terms of phonology and semantics. The comparisons that arise from the language variations in the two different dialects are more in the noun part, compared to the words and other terms mentioned from the results of the research above. From the comparison data of language variations in nouns, it is more likely to have phonological differences but have the same meaning. For example, in the example of the words 'ceurik' and 'cirek', the two words are words that are written and pronounced differently. However, it has the same meaning, even its use is the same.

The similarities found in the two dialects consist of only one word, such as the word 'môk' which is used by the two native speakers of the two regions. Where from one word has a different denotative meaning. In Pidie dialect speakers the word 'môk' means a tool made of cans and used to measure rice. It has a different meaning when said by Nagan Raya speakers, which is interpreted as a kind of glass that is used to hold water. Based on the explanation above, regarding the comparison of language variations in the Acehnese dialects of Pidie and Nagan Raya in the noun section, there are two comparisons that include differences and similarities in terms of meaning.

Based on the research above, the variation of the Acehnese dialect of the Pidie dialect with the Acehnese dialect of the Nagan Raya is caused by historical developments that experience contraction (abbreviation) in the syncope section. This is because the Acehnese dialect of the Nagan Raya dialect when communicating in the pronunciation of the font $/ \mathrm{r} /$ always experiences syncope. The font $/ \mathrm{r} /$ sounds as if it sounds melted or is not clearly pronounced, even though the speaker of the dialect can pronounce $/ \mathrm{r} /$ clearly.

\section{Conclusion}

The researcher concludes that the use of Acehnese dialect of Pidie and Nagan Raya dialect has variations in only some words. Native speakers of the Pidie dialect use the Acehnese language generally used in Pidie, while native speakers of the Nagan Raya dialect only occasionally use the dialect. However, the results of the study show that speakers of the Nagan Raya dialect use Indonesian more when interacting with other people. However, the variations of the Acehnese language used by the two speakers of different dialects do not feel awkward to interact with other people.

Based on the results of the research and its conclusions above, the researcher only provides suggestions for the future, it is hoped that the Acehnese people will be able to accept, absorb, and understand the meaning of the various dialects in the Aceh region. Thus, even though a person is a native speaker from a certain area, he or she can understand the Acehnese languages and other dialects that exist in various regions, in order to add insight into language variations. 


\section{References}

Bakar, Aboe et al. (2008). Acehnese-Indonesian Dictionary. Jakarta: Balai Pustaka.

Chaer, Abdul and Leonie Agustin. (2004). Early Introduction Sociolinguistics. Jakarta : Rineka Cipta.

Chaer, Abdul. (2012). General Linguistics of Indonesian. Jakarta : Rineka Cipta.

Chaer, Abdul. (2013). Introduction to Indonesian Semantics. Jakarta : Rineka Cipta.

Emir. (2012). Quantitative and Qualitative Educational Research Methodology. Bandung : Rajagrafindo Persada.

Gunawan, Imam. (2013). Qualitative Research Methods: Theory and Practice, Jakarta: PT. Earth Literature.

Ismail, et al. (2019). Social Changes in the Post-Tsunami Banda Aceh City. Budapest International Research and Critics Institute-Journal (BIRCI-Journal) Vol 2, No 1, Page: $45-50$

Keraf, Gorys. (2009). Diction and Language Style. Jakarta: Gramedia

Kridalaksana. (2001). Linguistics Dictionary. Jakarta: PT Gramedia Pustaka Utama.

Mahsun. (2007). Language Research Methods. Jakarta : PT Raja Grafindo Persada.

Mahsun. (2010). Genolinguistics. Yogyakarta: Student Library.

Nadra \& Reniwati. (2009). Dialectology, Theory, and Methods. Yogyakarta: CV Elmatera Publishing.

Ramlan. (2018). Some Steps for Language Maintenance in The Society and Individual. Budapest International Research and Critics Institute-Journal (BIRCI-Journal) Vol I, No 2, Page: 62-71

Sumarsono. (2002). Sociolinguistics. Publisher : SABDA (Institute for Religious, Cultural and Peace Studies).

Sumarsono. (2011). Sociolinguistics. Jakarta: Student Library.

Sugiyono. (2012). Business Research Methods. Bandung : Alphabeta.

Sugiyono. (2013). Quantitative, Qualitative, R\&D Research Methods, Bandung: CV. Alphabet.

dance. (2001). Speaking as a Language Skill. Bandung: Space

Tjiptadi, Bambang. (1984). Indonesian Grammar. Mold II. Jakarta : Yudhisthira.

Wibowo, Wahyu. (2001). Language Management. Jakarta : Gramedia.

Wijana, IDP (2009). Pragmatic Discourse Analysis: Theory and Analysis.

Wildan. (2010). The Acehnese Language Rules. Publisher : Geuceu. 